\title{
PRÁTICAS \\ DISCURSIVAS \\ DE DESOBEDIÊNCIA \\ E SEU VALOR \\ DE ACONTECIMENTO \\ NAS RELAÇÕES \\ DE PODER
}

\section{PRÁCTICAS DISCURSIVAS DE DESOBEDIENCIA Y SU VALOR EN LOS EVENTOS EN LAS RELACIONES DE PODER}

DISOBEDIENCE DISCOURSE PRACTICES AND THEIR VALUE ON POWER BALANCES

Pedro Navarro*

Cássio Henrique Ceniz ${ }^{* *}$

Universidade Estadual de Maringá

RESUMO: O artigo analisa movimentos discursivos de desobediência que se constituem como formas de resistência a certos dispositivos de poder. Para tanto, traçamos um percurso teórico e analítico que compreende os seguintes pontos: a) uma discussão a respeito do poder e do sujeito, com a atenção voltada para elementos que identificam o funcionamento do dispositivo da dominação masculina, incluindo a heteronormatividade e a virilidade; b) a retomada de aspectos da teoria do discurso que nos respaldam identificar o jogo estratégico que define uma posição de sujeito, cuja enunciação se manifesta como uma desobediência às estruturas sociais dos dispositivos elencados; c) a compreensão da noção de desobediência (GROS, 2018), interrogando seu funcionamento como prática discursiva. Escalonamos e analisamos os tipos de desobediência que, por seu valor de acontecimento na conjuntura sócio-histórica e política atual, manifestam atitudes de resistência frente aos dispositivos de poder que se sobrepõem aos sujeitos.

PALAVRAS-CHAVE: Discurso. Desobediência. Poder. Sujeito.

RESUMEN: El artículo analiza los movimientos discursivos de desobediencia que constituyen formas de resistencia a ciertos dispositivos de poder. Para ello, trazamos un camino teórico y analítico que comprende los siguientes puntos: a) una discusión sobre

\footnotetext{
* Doutor em Linguística e Língua Portuguesa. Professor Associado da UEM. Bolsista Produtividade em Pesquisa CNPq. LíderdoGEF-UEM e coordenadordoGT Estudos Discursivos Foucaultianosda Anpoll. E-mail: navarro.pl@gmail.com.

** Doutorando e mestre pelo Programa de Pós-Graduação em Letras da UEM. Bolsista Capes. Integrante do GEF-UEM e filiado ao GT Estudos Discursivos Foucaultianosda Anpoll. E-mail: cassioceniz@gmail.com.
} 
el poder y el sujeto, con atención centrada en los elementos que identifican el funcionamiento del dispositivo de dominación masculina, incluyendo la heteronormatividad y la virilidad; b) la reanudación de aspectos de la teoría del discurso que nos apoyan en la identificación del juego estratégico que define una posición de sujeto cuya enunciación se manifiesta como una desobediencia a las estructuras sociales de los dispositivos enumerados; y c) comprender la noción de desobediencia (GROS, 2018), cuestionando su funcionamiento como práctica discursiva. Escalamos y analizamos los tipos de desobediencia que, por su valor en los eventos y en el contexto socio-histórico y político actual, manifiestan actitudes de resistencia a los dispositivos de poder que se superponen sobre los sujetos.

PALABRAS CLAVE: Discurso. Desobediencia. Poder. Sujeto

ABSTRACT: This paper analyses disobedience discourse movements that build up as a way to resist specific power devices. To do that, we traced a theoretical and analytical path through the following points: a) a discussion about power and the subject with keen attention to elements that identify the works of the male domination device, included heteronormativity and virility; b) resuming of discourse theory aspects that help us identify the strategic game that defines the position of the subject whose enunciation manifests as disobedience to the social structure of the devices mentioned; and c) the understanding of the notion of disobedience (GROS, 2018), questioning its functioning as discourse practice. We sorted and analyzed the types of disobedience that, due to their value in the current socio-historical and political situation, manifest resistance to the power devices that superimpose themselves on the subjects.

KEYWORDS: Discourse. Disobedience. Power. Subject.

\section{INTRODUÇ̃̃O}

Muitas são as razões que nos levam a problematizar as possibilidades de existências outras, em face das inúmeras demandas sociais que reclamam, atualmente, pessoas comprometidas com aqueles que sofrem em decorrência das desigualdades sociais, dos preconceitos de várias ordens, da dominação exercida sobre seus corpos, sua liberdade de ir e vir, sua orientação sexual e como usam a linguagem, para citar apenas alguns exemplos de estruturas socais que balizam a soberania de leis, de políticas e de posicionamentos, supostamente, sem ideologia e em detrimento da vida.

Afirmar a vida, inclusive, deveria ser uma atitude implicada nos diversos mecanismos biopolíticos postos em ação pelos governantes, desde que estivessem a serviço de uma política de Estado, para usar uma expressão tão importante quanto gasta nos discursos dos que pleiteiam ou que ocupam postos de comandos de uma nação.

O ponto central deste artigo, contudo, não é discutir aspectos relacionados aos tipos de governo, suas formas de governamentalidade e o quanto a racionalidade neoliberal define regimes de conduta a seus cidadãos. Nossa inquietação é outra: tendo em vista um cenário político que acentua, ainda mais, a lógica do mercado, por corolário o individualismo e a competição, ao mesmo tempo em que acirra a intolerância gerada pelo preconceito de classe, de raça e de gênero, bem como intensifica a indiferença em relação às populações mais vulneráveis, haveria condições de possibilidade do exercício de práticas discursivas de desobediência que possam se constituir como formas de resistência ao medo, à hostilidade e à aversão ao que é diferente?

O recorte teórico e analítico precisa, também, ser mais bem delimitado. Para tanto, traçamos o seguinte percurso: em um primeiro momento, realizamos uma discussão a respeito do poder e do sujeito, com a atenção voltada para elementos que identificam o funcionamento do dispositivo da dominação masculina e a sua extensão na forma da heteronormatividade e da virilidade. Acrescentamos a essa reflexão dois conceitos que suportam posições de subjetividade em relação a tais dispositivos: vontade de verdade e coragem da verdade.

Em seguida, retomamos aspectos da teoria do discurso que nos respaldam a identificar o jogo estratégico (FOUCAULT, 2002) que define uma posição de sujeito que, por mais infinitesimal que possa parecer, enseja um processo de "saída" de um estado tal de menoridade (FOUCAULT, 2005a), à medida que sua enunciação se constitui como uma desobediência às estruturas sociais dos 
dispositivos elencados. Retornamos à problemática da função enunciativa que, nesses termos, possui um referencial, um sujeito, um campo associado e uma materialidade.

Finalizamos o artigo com um esforço de compreender a noção de desobediência (GROS, 2018), interrogando seu funcionamento como prática discursiva que, necessariamente, deve ser assumida por um si político, ético e livre. Na sequência, escalonamos e analisamos os tipos de desobediência que, por seu valor de acontecimento na conjuntura sócio-histórica e política atual, manifestam atitudes de resistência frente aos dispositivos de poder que, em maior ou em menor grau e de forma implícita e velada, dizem não à vida.

\section{A EXPERIÊNCIA DA SUBJETIVIDADE (SABER, PODER E ESTÉTICA DA EXISTÊNCIA) E OS DISPOSITIVOS DE PODER}

Iniciamos nossas reflexões tendo como tema a ideia de experiência da subjetividade. Vale lembrar que todo o projeto foucaultiano sempre esteve voltado para o sujeito e para sua experiência (FOUCAULT, 1984) com as relações de poder-saber-ética.

Retomar o texto A Arqueologia do saber pode ser um caminho para especificar a ideia de experiência do sujeito com o saber. Consideremos a formação discursiva da psiquiatria, por exemplo. Nela, a loucura é classificada mediante um sistema de delimitação, do qual participam determinadas instituições, tais como: a medicina, a justiça, a autoridade religiosa e a crítica literária e artística. As regras de formação desse discurso comportam, ainda, grades de especificação, pelas quais, como mostra o autor, diferentes tipos de loucura são classificados, separados, associados, reagrupados, colocados em associação uns com outros (FOUCAULT, 1972).

Desse modo, já na Arqueologia, anunciava-se, pelo recorte feito, que essa experiência do sujeito com o saber não passaria ao largo das relações de poder, porque se impunham como força que impedia o surgimento aleatório de objetos, de conceitos e de estratégias da psiquiatria:

[...] as regras de formação dos conceitos, qualquer que seja sua generalidade, não são o resultado, depositado na história e sedimentado na espessura dos hábitos coletivos, de operações efetuadas pelos indivíduos; não constituem o esquema encarnado de todo um trabalho obscuro, ao longo do qual os conceitos se teriam mostrado através de ilusões, preconceitos, erros, tradições. O campo pré-conceitual deixa aparecerem as regularidades e coações discursivas que tornaram possível a multiplicidade heterogênea dos conceitos. (FOUCAULT, 1972, p. 69-70)

Assim, para dar visibilidade à experiência do sujeito com a formação dos saberes, Foucault (1984) vai em busca da identificação e da descrição das práticas discursivas pelas quais pôde determinar as regras, o jogo do verdadeiro e do falso, isto é, as formas de veridicção.

Não perdendo de vista o saber, uma vez que a desobediência é concebida como tal, ou seja, deixa-se analisar por suas regras e por suas regularidades enunciativas, para sustentar a tese de que a prática da desobediência deflagra a experiência do sujeito com o poder, traçamos um fio condutor que nos auxilia a observar como se dá essa relação do sujeito com o poder em termos de experiência.

As análises genealógicas do poder mostraram que, em relação ao surgimento do sistema carcerário e da constituição do dispositivo da sexualidade, as condições de possibilidade políticas de saberes em circulação nesses dois campos não possuem uma relação direta com o Estado, mas em "[...] articulação com poderes locais, específicos, circunscritos a uma pequena área de ação, que Foucault analisava em termos de instituição" (MACHADO, p. XI). É neste sentido que Machado afirma que a tarefa da genealogia é considerar o saber como acontecimento e peça de um dispositivo político que se articula com a estrutura econômica: "Todo ponto de exercício do poder é, ao mesmo tempo, um lugar de formação de saber” (MACHADO, p. XXI).

A experiência do sujeito com o poder nos conduz, de saída, aos modos pelos quais o poder se exerce em um campo de procedimentos de governos. A análise seria assim conduzida, observando-se determinadas práticas discursivas disciplinares e biopolíticas. Foucault, 
contudo, incita-nos a refinar essa proposição, ainda em termos genealógicos. Somos chamados, portanto, a distinguir os acontecimentos, diferenciando as redes e os níveis a que eles pertencem, e tal análise só é possível se realizada "[...] em termos de genealogia das relações de força, de desenvolvimentos estratégicos e de táticas. Creio que aquilo que se deve ter como referência não é o grande modelo da língua e dos signos, mas sim da guerra e da batalha. A historicidade que nos domina é belicosa e não linguística" (FOUCAULT, 1979, p. 5).

A genealogia do sujeito em seu encontro com o poder conduz a análise dos discursos desobedientes a enfrentar a história "proveniência", na medida em que seu uso "agita o que se percebia imóvel, ela fragmenta o que se pensava unido; ela mostra a heterogeneidade do que se imaginava em conformidade consigo mesmo" (FOUCAULT, 1979, p. 21). Mais cortante ainda, "Ela deve mostrar o corpo inteiramente marcado de história e a história arruinando o corpo" (FOUCAULT, 1979, p. 22).

Por fim, a experiência do sujeito com si mesmo, que pode se dar nos termos de uma "dessubjetivação" (FOUCAULT, 2010). Nietzsche, Bataille e Blanchot dão o direcionamento para uma experiência-limite, cuja força é capaz de arrancar o sujeito de si mesmo, decompô-lo nos limites de sua própria impossibilidade. Com Nietzsche, "[...] reconhecemos parentesco em uma espécie de ponto de encontro entre o discurso sobre as experiências-limite, em que se tratava, para o sujeito, de transformar-se a si próprio, e o discurso sobre a transformação do próprio sujeito pela constituição de um saber.” (FOUCAULT, 2010, p. 306).

Essas três formas de experiência da subjetividade respaldam a formulação de três perguntas-chave que convergem para a problematização das práticas de desobediência sob investigação neste artigo: (1) haveria um feixe de relações que o discurso emprega para que a experiência da subjetividade se efetue na forma de saber? (2) haveria uma relação de forças genealogicamente dirigida que arruinaria a experiência do sujeito com seu corpo; e, por fim, (3) haveria um conjunto de práticas ascéticas pelas quais o sujeito possa quebrar a relação com si mesmo, perder sua identidade, isto é, encontrar outras formas de experiência como sujeito de uma ética do cuidado de si e dos outros?

Em síntese, o sujeito das práticas de desobediência é, ao mesmo tempo, aquele constituído pelas regras de formação, objetivado nas relações de poder, mas que sempre tem a possibilidade de viver outra vida, deixando-se transformar em direção a uma espiritualidade e a uma verdade, ou melhor, a verdade do sujeito.

Na busca de elementos que assentem nossas hipóteses acerca das práticas discursivas de desobediência, em especial sobre as quais nos debruçamos, encaminhamos as discussões para o terreno dos dispositivos de poder.

Um primeiro ponto a destacar tem a ver com o fato de que essa abordagem dos dispositivos se justifica por compreendermos que as lutas do presente não se voltam somente contra determinada instituição ou classe específica, mas contra determinadas "técnicas de poder". Foucault (1995) alerta para as lutas que se opõem às formas de dominação étnicas, sociais e religiosas; as que denunciam as formas de exploração que separam o indivíduo daquilo que produz; e as lutas que combatem tudo o que liga o indivíduo a ele próprio e asseguram assim a submissão aos outros.

Em virtude mesmo das demandas do campo teórico, iniciamos resgatando os estratos históricos de saber, como propõe Deleuze (2017), para associá-los aos dispositivos frente aos quais os sujeitos são convocados a fazer resistência, de antemão, furtando-nos a realizar uma genealogia de cada um em sua amplitude

Deleuze (2017) contribui sobremaneira com a percepção que podemos ter de dispositivo, ao pôr em relevo o funcionamento do par "visibilidades-enunciados", nas obras História da loucura, Vigiar e Punir e Nascimento da clínica, de Foucault. Deleuze observa que a análise de Foucault sobre o surgimento e as mudanças históricas em torno dos objetos de poder-saber permite observar que cada estrato de formação histórica em que tais objetos surgem, transformam-se ou desaparecem, possui seus regimes de visibilidade e de enunciabilidade: "Toda formação histórica vê aquilo que é capaz de ver, toda formação histórica vê tudo o que ela pode ver. E, correlativamente, toda formação histórica diz tudo o que pode dizer. Uma formação histórica se definirá com base em suas próprias evidências, ou seja, no seu regime de discursividades" (DELEUZE, 2017, p. 25). 
Nesses termos, o par "visibilidades-enunciados" é imprescindível para o funcionamento discursivo do exercício de poder dos dispositivos, visto que identifica as regras de formação dos saberes e dos efeitos de poder vinculados a esses saberes. Aproximando a leitura de Deleuze sobre as formações históricas com a que ensejamos fazer dos dispositivos, diremos que as evidências e as discursividades dos dispositivos não configuram o que se poderia chamar de mentalidade de uma época, o espírito que a animaria. O visível e o enunciável dos dispositivos são tanto o desdobramento das redes de ideias que operam em dada época quanto aquilo que torna possível trazer à luz o que se faz e o que se prova em uma época. Nessa rápida aproximação, diremos que a análise dos dispositivos nos permite observar as condições que tornam possíveis tanto os comportamentos quanto as mentalidades.

Chegar a esse ponto das reflexões requer, agora, que abordemos a relação entre o sujeito e o poder. O esforço está sendo feito no sentido de retomar noções e conceitos dos estudos foucaultianos e deles nos servir como termos-conceituais para as entradas discursivas no corpus sob investigação. Assim, qualificar os dispositivos na sua interface visibilidade e enunciabilidade é atribuirlhes o poder de lançar luz sobre indivíduos e fazê-los assumir certos discursos de "verdade". Como se dá essa engrenagem, essa dinástica do poder?

Tendo em vista uma das facetas do poder, que é o disciplinar, a dinástica do poder ocorre mediante um equilíbrio entre "capacidadecomunicação-poder" (FOUCAULT, 1995, p. 241). Assim, devemos considerar que a aplicação de capacidade objetiva requer que haja relações de comunicação, as quais, por seu turno, estão vinculadas às relações de poder e definem tarefas que devem ser realizadas, impõem tipos de conduta desejados, assim como administram formas de controle do tempo, da divisão do trabalho etc. O exemplo da instituição escolar dá a dimensão do funcionamento desse bloco "capacidade-comunicação-poder":

[...] sua organização espacial, o regulamento meticuloso que rege sua vida interior, as diferentes atividades aí organizadas, os diversos personagens que aí vivem e se encontram, cada um com uma função, um lugar, um rosto bem definido - tudo isto constitui um "bloco" de capacidade-comunicação-poder. A atividade que assegura o aprendizado e a aquisição de aptidões ou de tipos de comportamento aí se desenvolve através de todo um conjunto de comunicações reguladas (lições, questões e respostas, ordens, exortações, signos codificados de obediência, marcas diferenciais do "valor" de cada um e dos níveis de saber) e através de toda uma série de procedimentos de poder (enclausuramento, vigilância. recompensa e punição, hierarquia piramidal). (FOUCAULT, 1995, p. 241)

Essa dinâmica do poder responde pelo processo de disciplinarização dos sujeitos, haja vista o ajuste cada vez mais controlado, racional e econômico entre as atividades produtivas, as redes de comunicação e o jogo das relações de poder.

Pautar-nos em tais aspectos do poder de disciplinarização é um caminho para mais bem compreendermos os dispositivos contra os quais os sujeitos desobedientes fazem resistência. Na introdução deste artigo, elencamos a dominação masculina, acrescentando-se a virilidade e a heteronormatividade como componentes de realização desse tipo de poder. Consideramos que se encontram imbricados uns aos outros e que funcionam em rede nos processos de subjetivação; entretanto não seria equivocado supor que a dominação masculina, com seus regimes de visibilidade e de enunciabilidade, teria como tentáculos a heteronormatividade e a virilidade.

Por exemplo, a virilidade que se comunica por meio de gestos e de atitudes é sustentada pela dominação masculina e tem seus efeitos de poder em termos de reconhecimento. Atualizando-se, assim, na forma de bloco capacidade-comunicação-poder, espraia-se como relação de forças sobre os sujeitos. A análise de discursos midiáticos a respeito de empresárias que conseguiram lugar de destaque no mundo coorporativo dá visibilidade aos embates entre homens e mulheres, replica a competição entre sexos que se acirra nesse universo e expõe as dificuldades encontradas por algumas gerentes para comandar equipes predominantemente masculinas. Um aspecto de regularidade enunciativa nessa produção é o relato de experiência de mulheres que, conforme exposto nas reportagens, tiveram de se "comportar como homens" para conseguir o respeito e impor sua liderança (NAVARRO; SILVA, 2015).

Nosso propósito, no que tange a esses dispositivos, não é fazer um levantamento de sua genealogia, trabalho de fôlego e que demandaria um tempo bem maior para cartografar seus componentes definidores. Não despropositadamente, recorremos aos 
termos conceituais "visibilidades-enunciados" e "capacidade-comunicação-poder" para perfilar alguns aspectos que identificam esses domínios de poder sobre os homens e, mais adiante, aqueles que singularizam enunciados de desobediência.

Iniciando pela dominação masculina, consideramos que esse dispositivo tanto congrega quanto se retroalimenta da virilidade e da heteronormatividade. Bourdieu (2019) busca traços da violência simbólica que se exerce no social, destacando o corpo e a sujeição a que estão submetidas as mulheres. Alguns desses traços evidenciam as condições do exercício de poder dos homens, o que lhes garantem primazia nas estruturas sociais e em atividades produtivas e reprodutivas. Valendo-se da ideia de habitus, esse autor exemplifica a dominação masculina, tomando por base as divisões constitutivas nas relações de dominação e de exploração entre os gêneros:

Cabe aos homens, situados do lado do exterior, do oficial, do público, do direito, do seco e do alto, do descontínuo, realizarem todos os atos ao mesmo tempo breves, perigosos e espetaculares, como matar o boi, a lavoura ou a colheita, sem falar do homicídio, da guerra, que marcam rupturas no curso ordinário da vida. Às mulheres, pelo contrário, estando situadas do lado do úmido, do baixo, do curvo e do contínuo, são atribuídos todos os trabalhos domésticos, ou seja, privados e escondidos, ou até mesmo invisíveis e vergonhosos, como o cuidados das crianças e dos animais [...]. Os homens (e as próprias mulheres) não podem senão ignorar que é a lógica da relação de dominação que chega a impor e inculcar nas mulheres, ao mesmo título das virtudes e da moral que lhes impõem, todas as propriedades negativas que a visão dominante atribui à sua natureza, como a astúcia ou, para lembrar o traço mais favorável, a intuição. (BOURDIEU, 2019, p. 56-57)

A virilidade é uma das formas de manutenção e de reutilização da dominação masculina. Em termos de capacidade-comunicaçãopoder, destaca e faz ver o sujeito viril (o visível), ao mesmo tempo em que põe em circulação discursos (o enunciável) que suportam posições de subjetividade viris para serem ocupadas por homens e por mulheres, independentemente da identidade de gênero ${ }^{1}$ e da orientação sexual que assumem.

Bourdieu (2019) resume virilidade como capacidade reprodutiva, sexual e social atribuída a alguém; agrega a esses caracteres a aptidão para o combate e para o uso da violência. Aproximando essa definição da ideia de dispositivo, podemos afirmar que a virilidade é um dos poderosos instrumentos de condução de condutas que são constantemente reforçados pelas instituições. Certamente, a família e a religião funcionam como "superfícies primeiras" (FOUCAULT, 1972) de inscrição do acontecimento deste dispositivo no corpo dos sujeitos. No campo dos esportes, exemplifica Bourdieu, os jogos de luta participam dos esquemas sociais que pesam sobre o homem, pois é o momento de testar suas qualidades tidas como viris. As instituições, portanto, como analisa Foucault (2005b), desempenham um importante papel de vigilância, de normatização e de exame dos sujeitos, sendo por meio desses mecanismos que o corpo é marcado e condutas são impostas.

Haroche (2013) lembra que, independentemente do momento histórico em que se vive, a virilidade é vista como sinônimo de força física, simbólica e moral. Nessa direção, Vigarello (2013a) observa que a virilidade atravessa os tempos, as sociedades (suas expressões culturais e o fazer político-econômico), assim como práticas cotidianas, sejam elas individuais ou coletivas, que se efetivam tanto no meio urbano quanto no meio rural.

Nessa história de longa duração da virilidade, em sua estreita relação com a dominação masculina, as relações de poder se sobrepõem como efeito sobre o corpo, organizando, na forma de comunicação, certos códigos a serem internalizados no social. Neste sentido, levando-se em conta a relação capacidade-comunicação-poder, o viril se expressa pela aptidão que se tem para comandar e para tomar decisões racionais que são requeridas no exercício do poder. Ainda de acordo com Haroche (2013, p.16), "La virilité est l'elément central de la mémoire de la domination masculine. Celle-ci équivaut à la domination virile, sans pourtant s’y limiter: elle peut s'exercer sans qu'un homme soit physiquement viril, il suffit qu'il le soit mentalmente, sachant exercer à son profit la virilité physique des autres".

${ }^{1}$ Identidade de gênero é vista, neste artigo, como um efeito discursivo, uma vez que “[...] o gênero é sempre um feito, ainda que não seja obra de um sujeito tido como preexistente à obra" (BUTLER, 2003, p. 48). 
A virilidade não é somente algo que pertence ao universo masculino, visto que contempla um ideal de poder e de virtude, segurança e maturidade, confiança e domínio. Acrescentamos que esse aspecto mais abrangente da virilidade define comportamentos e formas de enunciação que podem se estender a todo o corpo social, constituindo-se, assim, um elemento tanto disciplinar quanto de controle dos sujeitos e do seu corpo.

Sem perder de vista uma história serial (FOUCAULT, 1972) que se movimenta entre continuidades e descontinuidades históricas, a virilidade solicita que interroguemos se, contemporaneamente, em virtude de movimentos contrários ao poder masculino, novas masculinidades emergem com valor de acontecimento, dado o fato de reorganizarem a memória desse poder, ou, por um efeito de continuidade, as práticas discursivas adotam como estratégia a permanência de virilidades hegemônicas que, na superfície discursiva, são apresentadas como novas masculinidades.

Como parte extensiva do poder de dominação masculina, entra em jogo o que poderíamos identificar como um conjunto de práticas e de códigos que encontram sustentação no relacionamento monogâmico, na fidelidade conjugal e na constituição da chamada família nuclear. A heteronormatividade, assim resumida, contribui para legitimar as práticas heterossexuais. Na esteira da relação entre capacidade-comunicação-poder, haveria o poder de normalização que, pelos enunciados que produz e faz circular, dão a ver o outro dessa prática, no caso, o homossexual como desviante. Ainda como efeito desse poder, em tais enunciados heteronormativos interditam-se outras possibilidades de experiência da sexualidade; em outras palavras, esse efeito pesa como força que oprime os homossexuais.

Uma vontade de verdade, então, nos termos expostos por Foucault (2006a), institui as práticas heterossexuais como normais, desejadas e necessárias, ao mesmo tempo em que reveste a homossexualidade do tabu do objeto (algo do qual não se deve falar, dado o caráter de anormalidade), rejeita-a e a separa das relações sociais, consequentemente atribuindo aos sujeitos dessa experiência sexual desviante e não disciplinada um lugar à margem, periférico, portanto, infame. O estabelecimento desse mecanismo de controle dos corpos e dos discursos desviantes atende a um dispositivo mais abrangente: a sexualidade.

Foucault (1988) analisa a scientia sexualis como um importante instrumento histórico de compreensão da relação entre verdade, sexualidade e subjetividade, dado o fato de que a ciência da sexualidade tem por finalidade explicar o sexo. As investigações desse autor mostram que, a partir dos séculos XVI e XVII, ocorreu, na sociedade ocidental, uma multiplicação de discursos que tinham por finalidade esquadrinhar, definir e iluminar todos os aspectos inerentes ao sexo. Para tanto, criaram-se dispositivos que multiplicaram discursos e produziram verdades sobre o sexo. O discurso médico, legitimado que é por relações de poder, embora revestido de uma aura de neutralidade científica, produz crescentemente tais verdades: a medicina do sexo associa-se fortemente à biologia (evolucionista) da reprodução. Essa associação do discurso sobre o sexo com o discurso científico legitima as verdades sobre a experiência do sujeito com a sua sexualidade.

A vontade de verdade dos dispositivos, uma vez reforçada por discursos como os da ciência, da religião e da família, por exemplo, cria oposições hierarquizadas, por meio das quais intervém a norma, disso resultando a distinção entre homem/mulher, heterossexual/homossexual, forte/fraco, dominante/dominado, macho/afeminado. O efeito de poder vinculado a esses discursos estabelece as desigualdades, na medida em que institui o primeiro elemento de cada par como positivo e superior. No tocante à heteronormatividade, suas formas prescritivas e decodificadas se impõem sobre a formação do indivíduo, ao exigirem dele uma identificação com aquilo que Butler (2005) chama de o fantasma normativo do sexo. No esforço de problematizar esse tentáculo da dominação masculina, com base no construto teórico que estamos elaborando, entra em cena o bloco capacidade-comunicaçãopoder, visto que o processo de subjetivação se dá em consonância com a regulação das práticas, dos comportamentos e dos desejos, evitando, assim, qualquer possibilidade de resistência (desobediência) ao que foi socialmente construído e estabelecido como conduta modelar.

Um estudo realizado por Miranda (2016) mostrou que a relação de hierarquia entre os sexos é um construto social acerca do homem e da mulher, o qual ora viriliza um e ora dociliza o outro. Constituindo-se sobre bases heterossexuais e falocêntricas, o mundo de dois sexos alicerça-se sobre uma concepção equivocada de sexo e de sexualidade, respaldada, como mostra a autora, pelo dispositivo heteronormativo. Acrescentamos que tal dispositivo encontra suas leis de existência em "temas e estratégias" (FOUCAULT, 1972) 
de um determinismo biológico que naturaliza as categorias de masculino e de feminino. Ainda segundo Miranda, a mulher está imersa em um processo de docilização e de virilização compulsórias em momentos distintos da história, isto é, trata-se de uma estruturação do dispositivo da sexualidade que ajusta os efeitos de verdade aos acontecimentos múltiplos e independentes. Para além dessa constatação, é preciso levar em conta, lembra a autora, que a virilidade não é um efeito comandado pelo corpo, mas uma construção social e um fenômeno psicológico, os quais dão acesso à virilidade. Perceber uma mulher protagonista de uma história da liberação sexual com todas as suas conquistas, desde a pílula contraceptiva, tendo como pano de fundo um homem que precisa adaptar-se a essa supremacia, pode ser um exemplo de virilidade à qual somente via discurso tal mulher teria acesso.

\section{A TEORIA DO ENUNCIADO: PONTOS DE TENSÃO ENTRE OS DISPOSITIVOS E AS DESOBEDIÊNCIAS}

Consideramos que o ponto de tensão entre os dispositivos e as desobediências caracteriza-se como um corpus não linguístico, mas enunciativo, portanto, belicoso, porque confronta posições de sujeitos, domínios associativos, temas e estratégias que configuram as regras de formação dos poderes e das resistências. A análise desse corpus deve estar, assim, pautada na ideia de enunciado com valor de acontecimento no interior do arquivo. Como ensina Foucault, a palavra arqueologia designa um tipo de pesquisa "[...] que se dedica a extrair os acontecimentos discursivos como se eles estivessem registrados em um arquivo" (FOUCAULT, 2006c, p. 257). Vale registrar, entretanto, que não dispomos de uma via de acesso para adentrar no interior do imenso arquivo, oral, escrito e/ou imagético que vem se constituindo, ao longo dos tempos, sobre essa tensão. Assim, o recorte se faz, com base em algumas práticas de desobediência, perfiladas mais adiante, no intuito de se observar o funcionamento discursivo da resistência frente aos dispositivos expostos na seção anterior.

A noção de acontecimento enunciativo, do modo como podemos depreender em Foucault (1972), funciona como um princípio teórico-metodológico, mediante o qual são apreendidas as regularidades discursivas existentes nas relações que os enunciados estabelecem entre si, nas relações existentes entre grupos de enunciados (relações de conformidade ou de confronto entre enunciados que formam uma rede interdiscursiva) e nas relações entre enunciados, grupos de enunciados e acontecimentos de ordem social, cultural, política e histórica:

[...] um enunciado é sempre um acontecimento que nem a língua nem o sentido podem esgotar inteiramente. Acontecimento estranho, por certo: inicialmente porque está ligado de um lado a um gesto de escritura ou à articulação de uma palavra, mas que, por outro lado, se abre a si mesmo uma existência remanescente no campo de uma memória, ou na materialidade dos manuscritos, dos livros e de qualquer forma de registro; em seguida, porque é único como todo acontecimento, mas que está aberto à repetição, à transformação, à reativação; finalmente, porque está ligado não apenas a situações que o provocam, e a conseqüência que incita, mas, ao mesmo tempo, e segundo uma modalidade inteiramente diferente, a enunciados que o precedem e o seguem. (FOUCAULT, 1972, p. 40)

O foco dado à teoria do enunciado justifica-se pelo fato de ser um ponto de entrada no corpus discursivo para se identificarem os movimentos de desobediência que os sujeitos do discurso realizam. Em torno dessa noção, gravitam uma perspectiva histórica, uma questão de método e uma teoria do sujeito, três pontos essenciais do que Foucault (2002) caracteriza como eixos de pesquisa.

O primeiro eixo detém-se na formação de domínios de saber, com ênfase nas práticas sociais, visto que elas podem "engendrar domínios de saber que não somente fazem aparecer novos objetos, novos conceitos, novas técnicas, mas também fazem nascer formas totalmente novas de sujeitos e de sujeitos de conhecimento" (FOUCAULT, 2002, p. 8). Em seguida, Foucault explicita sua questão de método, chamando o segundo eixo de "análise de discursos". O autor refere-se às pesquisas que se voltam para o aspecto linguístico, em especial, para um certo número de leis ou regularidades internas dos discursos. A análise que realiza das formas jurídicas mostra que os fatos de discursos não devem ser tomados somente em seu aspecto linguístico, posto que manifestam os jogos estratégicos de ação, de reação, de pergunta e de resposta, de dominação, de esquiva e de luta. Para Foucault (2002, p. 9), "O discurso é esse conjunto regular de fatos linguísticos em determinado nível, e polêmicos e estratégicos em outro. Essa análise de discurso como jogo estratégico e polêmico é, a meu ver, um segundo eixo de pesquisa”. O terceiro eixo de sua pesquisa consiste em uma reelaboração da teoria do sujeito, assim exposta: “Seria interessante tentar ver como se dá, através da história, a constituição de 
um sujeito que não é dado definitivamente, que não é aquilo a partir do que a verdade se dá na história, mas de um sujeito que se constitui no interior mesmo da história, e que é a cada instante fundado e refundado pela história” (FOUCAULT, 2002, p. 10).

Pautemo-nos, novamente, no par "visibilidades-enunciados". O que isso nos auxilia nas análises dos jogos de luta e de resistência entre os discursos de dispositivo e os de desobediência? Deleuze (2017) dá a direção, quando alude aos enunciados sobre a loucura, analisados por Foucault, os quais resultam em uma escala de sanções que leva os loucos a viverem com medo e evita, com isso, que eles prejudiquem a ordem moral e social. Deleuze segue mostrando que, a respeito das punições aplicadas a esses sujeitos, os enunciados dizem tudo: "Para os cuidadores da época, por exemplo, pode haver um louco que segura uma pedra enquanto passeia, o vigilante o observa - é preciso que o louco seja constantemente vigiado - e lhe diz: "Preste atenção! O que você tem aí na mão? Solta esta pedra..." O vigilante fica com a pedra... Ele pega uma pedra do chão: é um problema, porque perturba a ordem social” (DELEUZE, 2017, p. 67).

Nessa mesma direção, vamos encontrar nas "lettre de cachet" tudo o que se pode ver e dizer sobre a infâmia:

Foi para reencontrar alguma coisa como essas existências-relâmpagos, como esses poemas-vidas que eu me impus um certo número de regras simples: - que se tratasse de personagens tendo existido realmente; - que essas existências tivessem sido, ao mesmo tempo, obscuras e desventuradas; - que fossem contadas em algumas páginas, ou melhor, algumas frases, tão breves quanto possível; - que esses relatos não constituíssem simplesmente historietas estranhas ou patéticas, mas que de uma maneira ou de outra (porque eram queixas, denúncias, ordens ou relações) tivessem feito parte realmente da história minúscula dessas existências, de sua desgraça, de sua raiva ou de sua incerta loucura; - e que do choque dessas palavras e dessas vidas nascesse para nós, ainda, um certo efeito misto de beleza e de terror. (FOUCAULT, 2006b, p. 205)

Em outra oportunidade (NAVARRO, 2018), o funcionamento desse tipo de petição endereçada ao rei foi submetido à teoria do enunciado, formulada por Foucault (1972). Assim, o foco recaiu sobre o "algo a mais" que tal sistema permitiu investigar, haja vista o poder que atravessa os corpos infames. Pelo fato de pôr em ação um tipo de capacidade-comunicação-poder, as "lettre de cachet" investem-se de um valor de acontecimento que produz subjetividades no encontro com o poder:

O ponto mais intenso das vidas, aquele em que se concentra sua energia, é ali onde elas se chocam com o poder, se debatem com ele, tentam utilizar suas forças ou escapar de suas armadilhas. As falas breves e estridentes que vão e vêm entre o poder e as existências as mais essenciais, sem dúvida, são para estas o único monumento que jamais lhes foi concedido; é o que lhes dá, para atravessar o tempo, o pouco de ruído, o breve clarão que as traz até nós. (FOUCAULT, 2006b, p. 208).

E os enunciados de dispositivo, o que permitem ver e enunciar? Recorremos a Da Mata (2010) e a Albuquerque Júnior (2010), de cujos relatos e descrições é possível ter uma dimensão do regime de enunciados correspondente à dominação masculina e sua extensão em termos de virilidade.

O primeiro autor relata uma espécie de brincadeira que era feita nos encontros de rapazes, em sua cidade natal, a mineira São João Nepomuceno, nos anos 1950. Um rapaz do grupo apalpava “[...] o traseiro do amigo, questionando em tom jocoso: 'Tem pente aí?!', o que normalmente fazia com que a vítima desse um pulo para frente, protegesse as nádegas com as mãos e reagisse violentamente ao brinquedo, o que - e este era um dos objetivos da apalpadela - deleitava o grupo que atentamente observa sua reação". (DA MATA, 2010,p. 135)

Os demais rapazes punham-se a observar e a comentar, de modo debochado, a reação da vítima, que tentava, rapidamente, protegerse dos dedos alheios. O amigo que fazia isso estava à procura de um pente que, pelo costume da época, era carregado no bolso traseiro da calça.

Da Mata (2010) chama a atenção para o fato de que, se a vítima da brincadeira reagisse grosseiramente, era acusada de possuir uma maior sensibilidade onde fora tocada, o que poderia indicar certa tendência à homossexualidade passiva, um dos maiores inimigos 
do modelo de masculinidade adotado. Em seu relato, esse autor destaca, ainda, que a atitude mais acertada seria o controle, por parte do que fora alvo da brincadeira, e isso poderia até levá-lo a inverter a situação, pedindo, também jocosamente, que o atacante continuasse a lhe passar as mãos em suas nádegas.

Albuquerque Júnior, por sua vez, reúne alguns traços vistos como característicos do macho, na busca de elementos, digamos, identificadores desse tipo de masculinidade dominante. O autor pergunta como saber se um homem é um macho de verdade, e a resposta é observando o seu corpo. Acrescentamos que, sendo uma superfície de inscrição da virilidade, trata-se de um corpo que

[...] não deve deixar escapar nenhum gesto, nenhuma atitude, nenhum traço que possa ser definido como feminino. Um corpo retesado, em permanente estado de tensão, corpo sempre com músculos definidos e em alerta, nenhum relaxamento, nenhuma lassidão. Nenhuma delicadeza, corpo rústico, rude, quase em estado de natureza, recendendo a suor e testosterona, viril, másculo. Corpo onde se ressaltem pelos e músculos, que transpareçam força e potência. Mas, talvez, a verdade do macho esteja em seu comportamento, em seus gestos, em sua maneira de ser. Um macho que se preze é agressivo na vida e com as pessoas, caracteriza-se pela vontade de poder, de domínio, exige subordinados e subordinações, notadamente das mulheres. Um macho não deixa transparecer publicamente suas emoções e, acima de tudo, não chora, não demonstra franquezas, vacilações, incertezas. Um macho tem opiniões firmes e incontestáveis, tem uma só palavra, não aceita ser contrariado ou contestado, notadamente por mulheres (ALBUQUERQUE JÚNIOR, 2010, p. 29).

Tanto o relato da brincadeira “Tem pente aí?!" quanto a descrição do corpo do macho são indícios por meio dos quais podemos encontrar enunciados advindos do dispositivo da dominação masculina sobre as masculinidades. Dito de outro modo, esses dois excertos nos dão a ver o corpo masculino sendo testado e observado, bem como enunciando sua virilidade. Assim, o ver e o julgar nos permitem identificar os enunciados de dispositivo. Em termos de capacidade-comunicação-poder, diríamos que processo de legitimação desse corpo viril é definido em termos de visibilidades e de enunciados. Seja pelo lúdico, seja pelos traços físicos e psíquicos, entram nesse jogo do poder o julgamento dos pares e o olhar vigilante de uma sociedade heteronormativa.

Haveria um processo de "saída" do estado de menoridade masculina em relação a essa dominação?

\section{SUJEITO E PRÁTICAS DISCURSIVAS DE OBEDIÊNCIA/DESOBEDIÊNCIA AOS DISPOSITIVOS DE PODER}

Na densidade dos discursos, Foucault (1972) mostrou a diversidade de possibilidades de análises e, com isso, abriu caminhos para compreendermos as diferenças existentes entre os sujeitos, as posições e as funções que ocupam no interior de uma mesma prática discursiva ou instaurando práticas outras. Embora o sujeito do enunciado seja determinado, por ser uma função vazia, pode ocupar ou assumir posições diferentes, fato que orienta a análise a investigar as condições em que uma subjetividade desobediente possa emergir como acontecimento.

Para entender a constituição e a inscrição do sujeito na história do presente, as entradas analíticas se dão ancoradas nas proposições de Gros (2018), que nos levam a refletir sobre a desobediência a partir da obediência. Confessando incômodo com o estado atual da sociedade, esse autor empreende sua reflexão, perseguindo respostas à seguinte pergunta: por que desobedecer? Pelo que apresenta, a sociedade tem aceitado o inaceitável de tal modo que o mundo estaria, cada vez mais, tornando-se repugnante às futuras gerações. Diante de tantos problemas que atravessam a história, a obediência tem se manifestado por meio de ações de indivíduos irresponsáveis, que não se opõem às injustiças ou às indecências, conformados e submissos, portanto passivos e com ausência de reflexão. Por isso, defende uma "democracia crítica" e a ação "de um si político que contém um princípio de justiça universal” (GROS, 2018, p. 16).

A reflexão, a criticidade e o ato de pensar, por exemplo, devem ser tomados como uma atitude necessária ao sujeito. Quando isso deixa de acontecer, o sujeito afirma-se ou reforça-se como obediente. Vale ressaltar, porém, que a obediência não é compreendida pelo autor apenas como algo negativo. Em determinadas circunstâncias, essa prática é desejável, como princípio para a manutenção 
de certa organização/ordem da sociedade, das instituições e entre os sujeitos. No entanto, Gros destaca ainda que, da obediência, pode ser produzida uma existência desobediente. Não qualquer desobediência, mas, fundamentalmente, aquela que esteja ancorada em uma perspectiva ética e justa.

Ao instituir a justiça no centro do debate, revisitando A República, de Platão, Gros explica que ela reside em aceitar as coisas como são, sem fantasiar ou se acalentar em discursos inúteis. Afinal, “[...] a justiça é praticada por todo lado. Há sempre gente honesta o bastante para manter o mundo. Mas em que profundidade ela se mantém em nós?” (GROS, 2018, p. 205, grifo nosso). Esse espraiamento da justiça é mencionado por ser uma produção dos homens; assim, cada um tenta estabelecer meios vantajosos para si. Portanto, se as regras e as convenções criadas forem analisadas com base nesse questionamento, a justiça mantém-se apenas no exterior e/ou na superficialidade. Nesse caso, o sentido de justiça não está ligado a uma força interior e crítica que mantém o sujeito reto perante a um si ético. A relação de si para si precisa ser sensível e adquirir dimensões de uma organização social, haja vista a necessidade de que, "[...] em cada um, seja sempre o que há de mais elevado que comande. A justiça é o que faz resistir perante si mesmo. Não ceder. E é do interior que eu me mantenho" (GROS, 2018, p. 211).

Quando o sujeito se curva às injustiças, às desigualdades e aos interesses privados, perde-se de si mesmo, desse que é o seu primeiro e principal companheiro. Existe sempre o espaço, o tempo e a possibilidade de pensar, escolher e agir. A depender das escolhas, há um preço a se pagar. O pior deles é uma existência destituída e/ou desprezada de si. A noção de justiça, de quem assume a posição de um si político, deve disponibilizar-se ao que é coletivo e social, portanto pensar bem, questionar, não aceitar aquilo que foi naturalizado e fazer sempre outras escolhas, já que somos autorizados e chamados a isso, pois estamos em constante construção.

No processo que é fazer da existência uma obra de arte, o sujeito não é dispensado do pensar. Pelo contrário, recai sobre ele a responsabilidade de não poder atribuir ao outro essa tarefa. Tanto a prática da obediência quanto a da desobediência exige do sujeito o pensar por si próprio, sem transferências ou dispensas. Gros é enfático: “A responsabilidade é um processo de subjetivação, e, no melhor do que se chama "sujeito", encontramos a descoberta em si dessa parte de indelegável. [...] O sujeito da responsabilidade [...] sou eu no sentido em que não sou os outros" (GROS, 2018, p. 192).

O sujeito indelegável é ético, político e cobra dignidade e humanidade universal. Segundo Gros, é um sujeito filosófico que é princípio de atividade, por isso, "[...] dá ou constrói sentido, projeta categorias. A responsabilidade faz encontrar outro sujeito, um sujeito que não é descoberto como uma irrupção. Torno-me, por e para mim mesmo, um sujeito de sentir sobre meus ombros esse peso, peso de meus erros, peso do sentido, peso do outro e do mundo" (GROS, 2018, p. 191-192).

Essa relação de poder e de resistência que, a nosso ver, caracteriza o jogo estratégico da obediência/desobediência deixa observar a possibilidade de deslocamento da humanidade, em seu movimento, contínuo e descontínuo, de abandono daquilo que se tem (re)produzido como hegemônico, ao qual Gros (2018) classifica como "absurdo" e/ou "irracional" na sociedade. A desobediência, sobretudo, não a naturalizada, é a que conclama os sujeitos ao ato de pensar, refletir, criticar e questionar. Ao mesmo tempo, somos interpelados a praticar a obediência, não, obviamente, aquela passiva e carente de reação, mas a que se exerce, mediante um exercício de consciência e de uma existência ética.

Uma vez que a ética perpassa as práticas de obediência e de desobediência, podemos considerar tais práticas legítimas ou não. Isso vai depender, por exemplo, do modo como os enunciados e as posições de sujeito são materializados. Não obstante o livre arbítrio que os sujeitos possuem, realizar um exame de consciência é condição fundamental para que pensem no bom governo de si e se responsabilizem também pelo governo que fazem dos outros. Essa é uma das condições destacadas por Foucault (2010b), em sua incursão pela cultura do cuidado de si, praticada na antiguidade greco-romana. Embora essa cultura tenha sofrido descontinuidades históricas ao longo dos séculos, é um acontecimento no pensamento ocidental moderno, como acentua esse autor, de tal sorte que o exame de consciência possa ser um caminho para um bom governo. A premissa é simples, porém tão longe de ser posta em exercício: se cada um fizesse o seu exame e observasse a justiça, possivelmente, não teríamos o cenário tão desigual e injusto que tanto mal causa aos cidadãos. 
O sujeito pensante, esse que aparece na proposta de Gros (2018, p. 214), "é a possibilidade contínua de desobedecer a si mesmo”. Não é soberano, mas concede espaço para a dúvida; defende "a ideia de humanidade por meio de protestos, recusas claras, indignações, desobediências formalizadas"; pela humanidade, provoca o deslocamento do sujeito em relação a si; é e precisa se "descobrir insubstituível para pensar, julgar, desobedecer, o que nos dá acesso ao universal” (GROS, 2018, p. 216); e tem coragem para encontrar a "urgência e a honra eternas, intempestivas, da verdadeira política, a das desobediências" que habitam os sis indelegáveis.

\subsection{ESCALONAMENTO DE TIPOS DE DESOBEDIÊNCIA QUE DÃO VISIBILIDADE A MOVIMENTOS DE RESISTÊNCIA EM PUBLICAÇÕES ON-LINE E NAS MÍDIAS SOCIAIS}

Na esteira dessa discussão sobre o sujeito (des)obediente, em várias passagens, Gros aprofunda as possibilidades de entendimento e de manifestação dessas práticas. Dentre os tipos de desobediência que dão visibilidade a tais posições de sujeito e a esse tipo de enunciação, uma análise prévia reuniu um importante arquivo de discursos desobedientes, cujos enunciados organizam-se em torno das seguintes práticas:

1) práticas discursivas de desobediência pela língua: a polêmica em torno da linguagem inclusiva;

2) práticas discursivas de desobediência pela linguagem: textos que usam expressões belicosas para fazer referência a acontecimentos, reforçando e replicando o privilégio militarizado de uma masculinidade dominante sobre outras masculinidades e outras feminilidades diversas;

3) práticas discursivas de desobediência ao machismo estrutural. Há, por exemplo, um conjunto de discursos desobedientes em ambientes de trabalho, com destaque para o "Guia antimachismo no trabalho", produzido por mulheres trabalhadoras do Ifood;

4) práticas discursivas de desobediência que visam a instituir, nas mídias sociais, outras formas de masculinidades possíveis: "Ressignificando masculinidades", "Rede Brasil de masculinidades", "Coletivo de homens negros", "Fundación Colectivo Hombres y Masculinidades", "De machos a HOMBRES", "Tejiendo masculinidades indígenas libres de violência" e "Rodas de masculinidades online com adolescentes”.

Na impossibilidade de analisar essa formação discursiva em sua amplitude, direcionamos nossa atenção para discursos que evidenciam temáticas sobre as masculinidades nas mídias sociais. Retiramos desse arquivo algumas sequências enunciativas (SE), seguidas da ordem numérica em que aparecem nesta seção.

Alguns acontecimentos discursivos emergem por meio da Rede Brasil de Masculinidades, em especial na sua página do Facebook e em discussões realizadas pelo grupo, via WhatsApp, que pautam e problematizam aspectos relacionados ao masculino e desdobramentos, tais como: gênero, sexualidade, saúde, paternidade etc. Em atividade desde 2011, uma das publicações (Imagem 1) é sobre a missão do coletivo.

O enunciado da SE 1 explicita o objetivo da Rede e, com isso, marca a posição de sujeito desobediente, que se expressa por meio de uma enunciação que elenca ações que visam a instituir práticas contrárias ao dispositivo de poder da dominação masculina. Uma dessas ações, a que reúne, a nosso ver, outras dela decorrentes, apela para um trabalho de "desconstrução de estereótipos e preconceitos que levam à violência e à Morte dos que ousam expressar a multiplicidade de SER HOMEM”. Historicamente, as práticas vinculadas a esse dispositivo reiteram uma padronização que considera apenas o que está limitado a um conjunto de traços (corpo, etnias, gestos, roupas, entre outros), supostamente, definidor do ideal de homem. O que se destoa disso pode ocasionar a "violência" e a "morte". Assim, o destaque enunciativo dá visibilidade a esse ideal do que seja homem, ao mesmo tempo em que enuncia a violência já pressuposta pelo dispositivo de poder. 
SE 1:

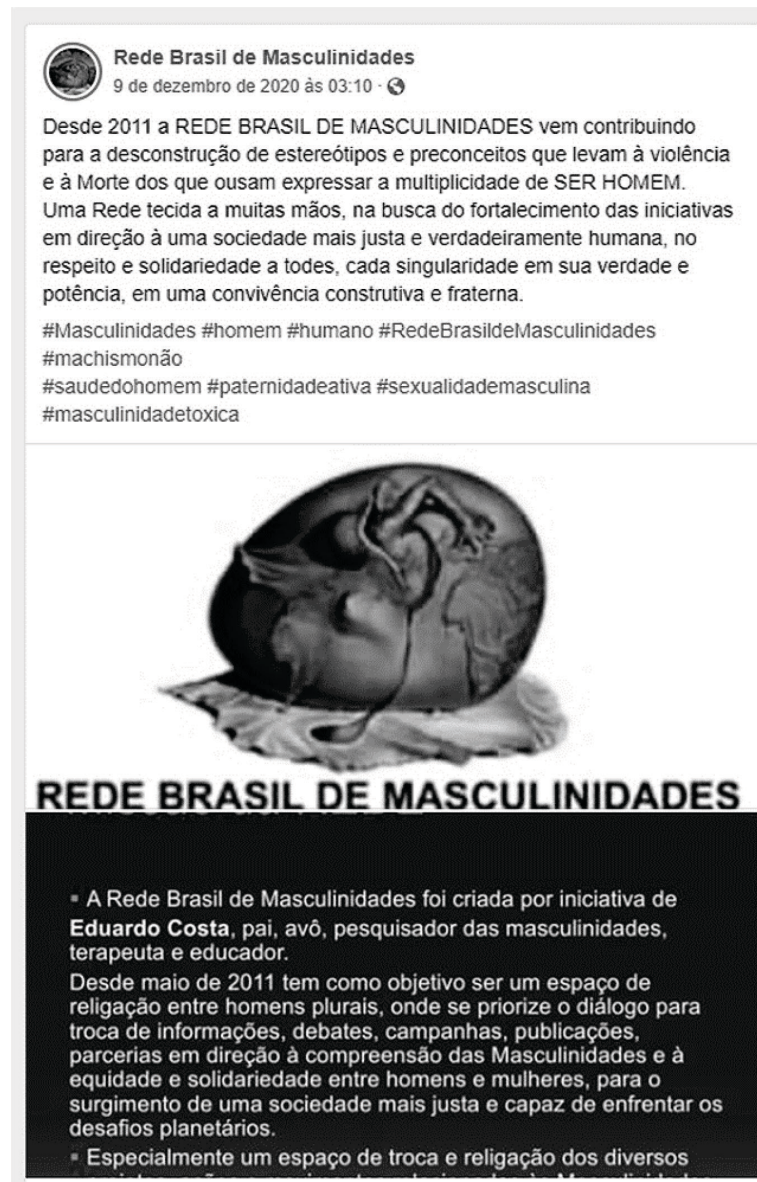

Imagem 1: Missão da Rede

Fonte: Rede Brasil de Masculinidades (2020)

As escolhas lexicais dão conta, também, de singularizar essa enunciação como parte de um exercício da desobediência. Consideremos, por exemplo, a presença das palavras "rede", "justa" e "humana". Rede associa-se ao domínio do que é coletivo, social, sendo, ainda, formada por "muitas mãos" que auxiliam no efeito de coletividade. Parece-nos haver, ao menos em nível de formulação, uma tentativa (processo) de posicionar o homem como participante de um coletivo que atua para a construção de um outro tipo de sociedade. Esse apelo surge como contraponto a um "campo associativo" (FOUCAULT, 1972), formado pelo dispositivo de poder contra o qual se faz resistência, dispositivo cujos elementos discursivos instituem práticas atreladas ao individualismo, à injustiça e à falta de humanidade. Tendo em vista que a desobediência está relacionada ao cuidado de si, como propõe Gros (2018, p. 181), "é pelo cuidado de si que nos impedimos de cometer abominações, de participar de empreitadas criminosas. [...] Não se trata de cuidar de si no sentido de uma postura egoísta, individualista, mas de permanecer vigilante nesse núcleo ético que habita cada um". O efeito do enunciado é justamente de uma organização que insurge no sentido de transgredir, abandonando as possibilidades de uma obediência conformada, fundada que está nas tradições e nos hábitos. A missão da rede, pois, expressa a necessidade de os indivíduos se constituírem como sujeitos homens desobedientes ao dispositivo de poder, à medida que consigam uma saída do estado de inércia coletiva em que se encontram.

Na mesma direção, o Ressignificando Masculinidades também produz discursos e promove encontros sobre a diversidade de vivência da masculinidade, a considerar pelo fato de se dirigir a "pessoas que se identificam como homem". Esse endereçamento produz um efeito contrário ao dispositivo da virilidade, se levarmos em conta que este oferece os elementos legitimados culturalmente do que se entende por homem. Em outros termos, Ressignificando realiza um movimento contrário ao do dispositivo de poder, pois, em vez de fechar, abre os indicadores que fazem alguém se sentir como homem. Como parte desse movimento de 
contraconduta, está a própria possibilidade de não obediência a padrões hegemônicos, uma desobediência à vontade de verdade de uma masculinidade enunciada no singular e normalizada.

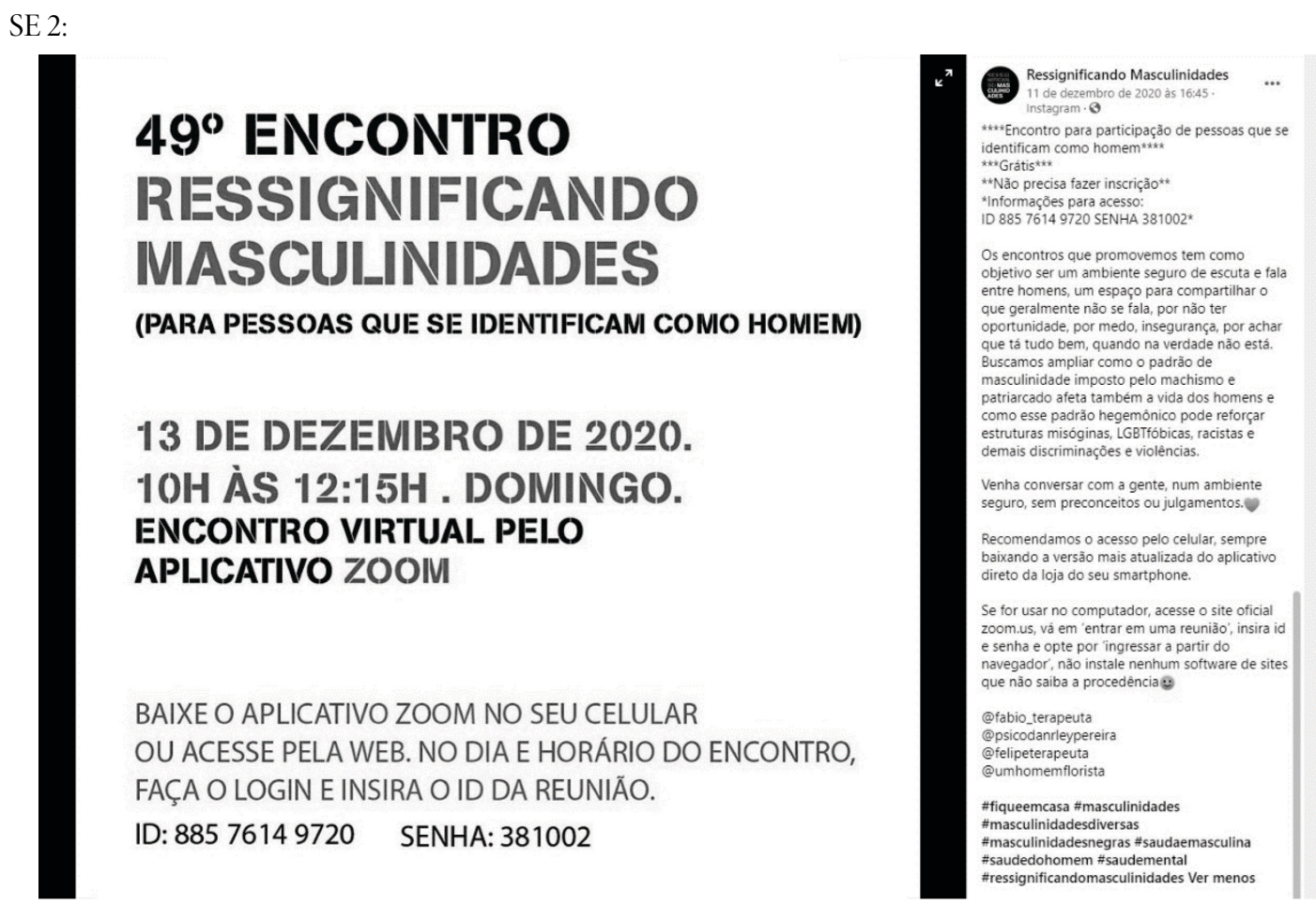

Imagem 2: $49^{\circ}$ Encontro Ressignificando Masculinidades

Fonte: Ressignificando Masculinidades (2020)

Nos objetivos do grupo, tal como informados na Imagem 2, o enunciador assim se posiciona:

SE 3:

"Buscamos ampliar como o padrão de masculinidade imposto pelo machismo e patriarcado afeta também a vida dos homens e como esse padrão hegemônico pode reforçar estruturas misóginas, LGBTfóbicas, racistas e demais discriminações e violências" (Ressignificando Masculinidades, 2020).

Mais uma vez, o discurso da violência e o do preconceito emergem, indicando a regularidade que perpassa as condições históricoculturais e dá ancoragem enunciativa para a irrupção de desobediências a essa ordem hegemônica. Em termos discursivos, para que isso ocorra, entra em cena um jogo estratégico que se vale, justamente, do par visibilidades-enunciados como uma forma de fazer resistência ao tipo de sujeito masculino que o dispositivo da dominação masculina e o da heteronormatividade produzem e dão a conhecer, a saber: um homem machista, misógino, homofóbico e racista. Reconhecer esse tipo de masculinidade predominante, socialmente aceita, infelizmente, mas que causa tanto mal a si mesmo e aos demais indivíduos, é uma forma de autoconhecimento e de compreensão de outras possibilidades de subjetivação promovidas pelos encontros do Ressignificando Masculinidades.

Considerando-se, ainda, o jogo estratégico posto em funcionamento pelos discursivos desobedientes, na SE sob investigação, chamamos a atenção para três elementos que especificam o caráter de acontecimento desses discursos em relação ao poder: o primeiro tem a ver com a produção de um lugar de subjetividade atravessada pela responsabilidade. Para Gros, o sujeito da responsabilidade é aquele que chama para si a responsabilidade daquilo que acontece no mundo; é aquele que deve reconhecer que "o apelo vindo do fundo do sofrimento" se dirige a ele, posto que está "imerso neste mundo" (GROS, 2018, p. 192). Trata-se, pois, de um eu indelegável, porque o sujeito da responsabilidade é ele mesmo e não os outros; é ele quem deve fazer diferença por meio de suas práticas. O segundo elemento refere-se ao fato de que o Ressignificando Masculinidades se apresenta como um espaço para a emergência de outras práticas discursivas que fortalecem o coletivo. Um dos aspectos identificadores desse tipo de discurso é que "[... a capacidade de desobedecer juntos volta a ser sensível, contagiosa, quando a experiência do intolerável se adensa até se tornar uma evidência social”. (GROS, 2018, P. 17). O terceiro elemento nos permite observar que, na esteira de Deleuze (2017), a SE faz 
ver e diz tudo sobre o exercício do poder, na medida em que o enunciado permite observar uma prática de desobediência que denuncia as técnicas de poder do dispositivo de dominação masculina: o enunciado apresenta as características negativas e intoleráveis desse dispositivo, questiona esse coletivo sobre o quanto o seu outro (sua porção tóxica) lhe afeta e tenta "ampliar o padrão de masculinidade", no esforço de iluminar um processo de saída do estado de obediência passiva ao machismo e ao patriarcado.

A educação positiva, posta em ação no interior das masculinidades desobedientes, é outra prática discursiva que faz resistência, por exemplo, a enunciados, do tipo "coisas de homem". Enunciados que mantêm essa identidade fazem alusão a um campo associado, formado pelos dispositivos de poder já expostos, ao mesmo tempo em que interditam e rejeitam possibilidades diversas, instaurando-se como uma ordem discursiva (FOUCAULT, 2006a) que cobra obediência dos sujeitos. Um dos enunciados que margeiam essa máxima encontra-se na SE 4: "Homens não tem jeito com crianças" (Imagem 3). No entanto, diante de um sujeito que pratica um diálogo interior consigo, a dúvida se manifesta em forma de questionamentos: "Quem disse isso!? Aonde está escrito isso!? Por quê!?" O sujeito enunciador posiciona-se em uma perspectiva reflexiva, que desconstrói o que há muito tem se repetido e ensinado. Em ação, faz uma espécie de chamamento, desperta para a mudança no processo de educação para uma masculinidade positiva, sustentada pelas vias do cuidado e da sensibilidade.

SE 4:

"Mentiras que nos contam!!

HOMENS NÃO TEM JEITO COM CRIANÇAS.

Quem disse isso!? Aonde está escrito isso!? Por que!?

Durante nossa vida, educação e criação, nós homens somos afastados do CUIDADO.

Aprendemos a ser cuidados, aprisionados em ensinamentos como: seja forte, corajoso, garanhão, provedor do lar, destemido, autoconfiante, agressivo, firme e etc.

Porém não nos ensinam a CUIDAR. Seja de nós mesmos, o auto cuidado masculino, entender nosso corpo, nossas emoções, preservar nossa saúde. E tbm a cuidar de outra pessoa, seja ela uma criança, uma mulher, outro homem e etc.

CUIDAR é uma tecnologia como qualquer outra. Um conjunto ou sistema de técnicas para exercer uma função. A Função de CUIDADOR.

Não que prover o sustento e a segurança não sejam cuidados. Essas duas funções tbm são cuidados. Mas não só!!!

Nós homens não podemos nos privar dos outros cuidados que são importantes tbm. Primeiro, pq é muito gostoso fazê-los, o cuidado não é e não precisa ser alienante.

E segundo, alguém precisa fazer os outros cuidados tbm, e na maioria das vezes é exercido pelas mulheres.

Olhe para a foto acima e responda:. É justo com essas crianças fazê-las perder qualidades tão nobres como sensibilidade, empatia e afeto? Para que corta-las o acesso de aprender a cuidar?

Em nossas rodas de conversas, oficinas e palestras sempre pedimos para os homens presentes acessarem suas lembranças afetivas de quando eram cuidados, e de quando cuidaram de alguém. E lembrarem desses sentimentos.

Precisamos deixar nossos filhos e meninos a brincarem com jogos e brincadeiras que ensinam a cuidar tbm. A terem referências de homens exercendo esse papel de cuidar. E ter contato afetivo com outras crianças menores.

CUIDAR tem a ver com afeto. Pois é o ato de afetar e ser afetado.

Quando um homem CUIDA, ele está sendo CUIDADO tbm!!” (Rede Brasil de Masculinidades, 2020). 

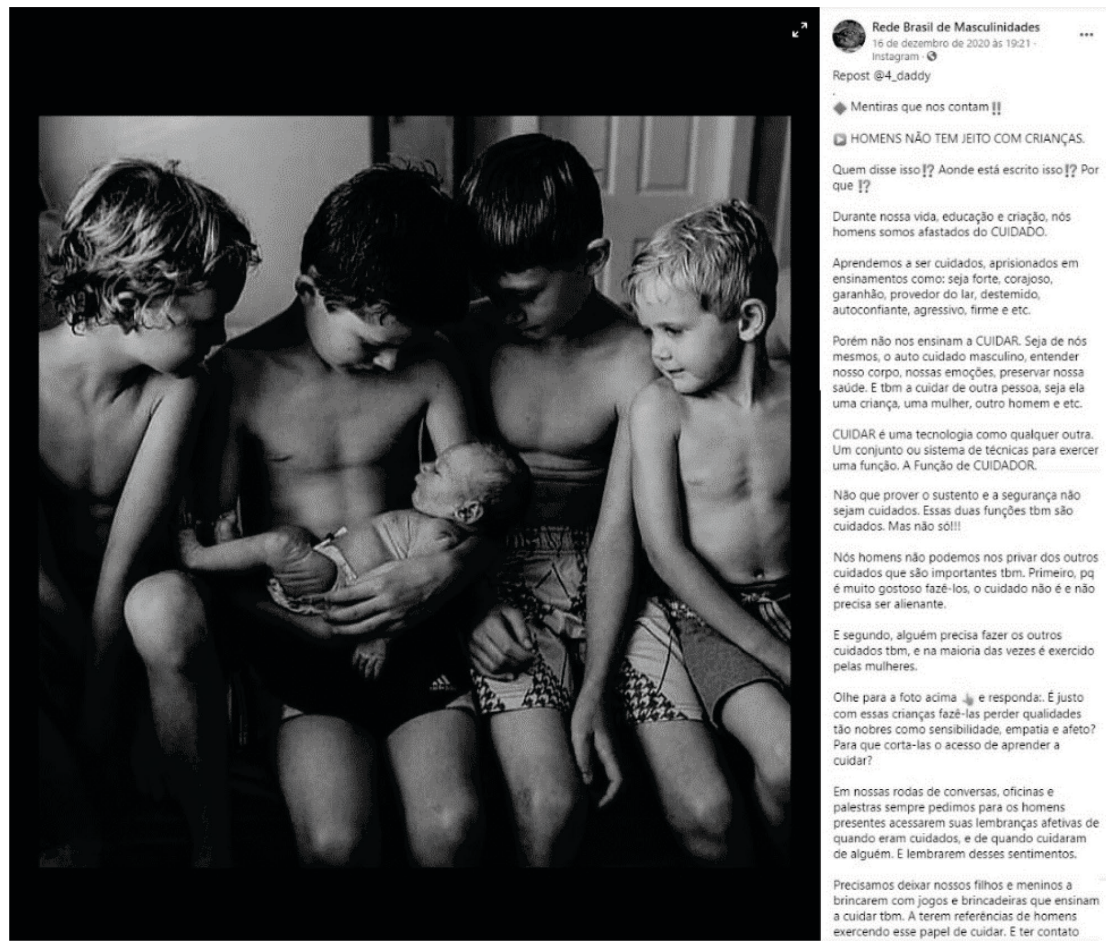

Imagem 3: Mentiras que nos contam

Fonte: Rede Brasil de Masculinidades (2020)

Esse sujeito discursivo, por ser levantar em defesa de outras formas de educação de homens e de meninos, encontra-se no lugar da desobediência, se comparado a outros homens que sustentam e replicam, por meio de palavras (o dizível) e de ações (o visível), a heteronormatividade e a virilidade. Nas palavras de Gros (2018, p. 209),

Educar é fazer entrar na alma belas histórias. A ética, profundamente em nós, é nossa parcela de infância. Não somos morais por consciência do dever, inteligência crítica. Somos morais por nos sentir convocados a agir, e é a imaginação das narrativas que sustenta.

Narrativas como essas, que emergem dos coletivos que defendem a pluralidade e a instituição de outras masculinidades, são possibilidades de um resgate da humanidade que tem se perdido, assim como uma tentativa de retornar imperativos que dão lugar a outra constituição de sujeitos. Afinal, “desobedecer é uma declaração de humanidade” (GROS, 2018, p. 17).

Entretanto, o sujeito não é somente o da desobediência. A obediência também se manifesta nas práticas discursivas, em determinadas condições, estabelecendo um jogo duplo, como expresso na SE 5 (Imagem 4). Assemelhando-se a um guia, uma sequência de textos e imagens, publicada na página da Rede Brasil de Masculinidades, elenca algumas atitudes que podem ser adotadas por homens que se sentem chamados (responsáveis por) a apoiar as agendas feministas. 
SE 5:

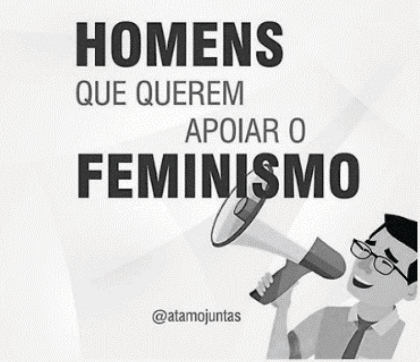

CONVERSE COM SEU

AMIGO QUE NÃO

PAGA PENSÃ̃O

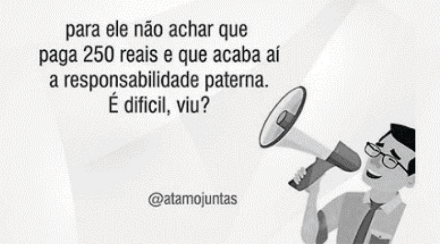

NÃO DIGA

QUE É FEMINISTA

porque essa é uma luta nossa,

sobre nosso lugar de fala.

Seja um apoiador.

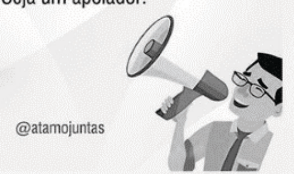

TENHA

RESPONSABILIDADE

AFETIVA

reveja e remodele a forma

de se relacionar com as mulheres.

Tenha empatia e honestidade

sobre as suas intençōes.

@atamojuntas

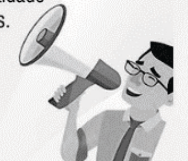

FALE SOBRE

MASCULINIDADE

TÓXICA

porque isso é prejudicial, inclusive

para vocês. Então, se informar sobr

o assunto vai servir para você

repreender seus amigos

machistas

@atamojuntas

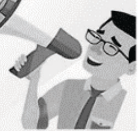

\section{EN-TEN-DA}

QUE NÃO EXISTE

ESTUPRO CULPOSO

e que sexo precisa de consentimento,

se não tem é ESTUPRO.

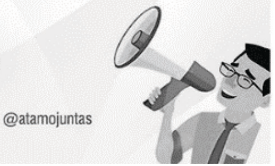

Imagem 4: Homens que querem apoiar o feminismo

Fonte: Rede Brasil de Masculinidades (2020)

A SE instaura uma posição de sujeito obediente ao dispositivo do feminismo para ser ocupada por homens, mas não se trata de uma "obediência passiva" (GROS, 2018). É uma obediência consciente, se considerarmos que a cada instrução está vinculado um efeito de poder injuntivo, mas que não se efetiva apenas no ato de instruir: o que se enuncia nessa sequência enunciativa é a necessidade de se fazer uma espécie de exame de consciência, de reflexão sobre as condutas, sobre o que pode causar sofrimento e o que é possível fazer para mudar essa situação de dor. Inspirados nas reflexões de Gros, podemos afirmar que aderir à agenda feminista é acreditar na humanidade. Assumir esse lugar também é se responsabilizar e defender a equidade entre homens e mulheres. É a obediência ao si político que se preocupa consigo e com os outros. A desobediência, por outro lado, pode ser compreendida nessa prática em relação ao dispositivo da masculinidade soberana, que tende a inferiorizar o que é feminino e seus movimentos socioculturais, intensifica a porção tóxica da masculinidade, realiza o chamado abandono parental e não demonstra responsabilidade afetiva.

\section{CONSIDERAÇÕES FINAIS}

As reflexões aqui empreendidas nos levam a enfatizar alguns pontos, tanto no que concerne à revisão teórica feita, quanto às análises discursivas. Assim, em linhas gerais, a análise das práticas discursivas de desobediência precisa:

a) tornar visível uma guerra real, guerra que a história da soberania, com seu discurso de poder, procura sufocar e mascarar (no Brasil, não há racismo; a mulher provocou o estupro; homem é assim mesmo etc);

b) reativar essa guerra por meio de um saber histórico (dominação masculina), utilizando-se desse saber como elemento tático no interior da guerra real que se trava;

c) animar-se, sempre, com a possibilidade de uma inversão final da relação de forças e o deslocamento definitivo no exercício do poder.

Isso posto, a desobediência pode ocorrer mediante um processo de saída do estado de menoridade do homem; ela se efetiva pelo cuidado de si e dos outros e pela coragem da verdade, os quais o conduzirão a uma experiência com o si ético (uma transfiguração, nos termos da cultura do cuidado de si). 
As práticas discursivas de desobediência, na sua relação com os dispositivos de poder, produzem uma obediência ao si indelegável, como já mencionado. Elas representam a coragem do sujeito que, ao "responder presente", assume responsabilidades, sem transferir ao outro aquilo que pode fazer para a construção de um mundo mais justo e menos violento.

De acordo com Gros, "Descobrir em si o eu indelegável é se sentir chamado a agir para os outros, a fazer existir essa justiça cuja urgência sentimos" (GROS, 2018, p. 157). Assumir-se responsável é uma via possível para construir outros pensamentos, outras práticas, enfim, outras experiências, em termos de saber, de poder e de subjetividade.

Uma última observação: o grande arquivo da desobediência estaria em articulação com outro grande arquivo, o da infâmia, de modo que poderíamos, em trabalhos futuros, testar a seguinte formulação: o sujeito é desobediente porque é infame ou, sendo infame, pratica desobediências? Eis a história de Antígona e o que sua infâmia desobediente lhe custou, em virtude da coragem da verdade (GROS, 2018).

\section{REFERÊNCIAS}

ALBUQUERQUE JÚNIOR, D, M. Máquina de fazer machos: gênero e práticas culturais, desafio para o encontro das diferenças. In: MACHADO, C. J. S; SANTIAGO, I. M. L; NUNES, M. L. S. (org.) Gêneros e práticas culturais: desafios históricos e saberes interdisciplinares [online]. Campina Grande, 2010. p. 23-33.

BOURDIEU, P. A dominação masculina: a condição feminina e a violência simbólica. Trad. Maria Helena Kuhner. 16. Ed., Rio de Janeiro: Bertrand Brasil, 2019.

BUTLER, J. Problemas de gênero: feminismo e subversão da identidade. Trad. Renato Aguiar. Rio de janeiro: Civilização Brasileira, 2003.

BUTLER, J. Corpos que importam: sobre los limites materiales y discursivos del sexo. Buenos Aires: Paidós, 2005.

DA MATA, Roberto. Tem pente aí? Reflexões sobre a identidade masculina. Revista Enfoques - Revista Eletrônica dos Alunos do PPGSA/IFCS/UFRJ, Rio de Janeiro, v. 9, n. 1, p. 131-151, ago.

DELEUZE, G. Michel Foucault: as formações históricas. Trad. Cláudio Medeiros, Mario A. Mariano. São Paulo: $n$-1 Edições, Editora Filosófica Politeia, 2017.

FOUCAULT, M. A arqueologia do saber. Trad. Luiz Felipe Baeta Neves. Petrópolis: Vozes; Lisboa: Centro do Livro Brasileiro, 1972.

FOUCAULT, M. Microfísica do poder. Organização e tradução de Roberto Machado. 13. ed. Rio de Janeiro: Edições Graal, 1979.

FOUCAULT, M. História da sexualidade 2: o uso dos prazeres. Trad. Maria Thereza da Costa Albuquerque. Rio de Janeiro: Edições Graal, 1984.

FOUCAUlT, M. História da sexualidade I: a vontade de saber. Trad. Maria Thereza da Costa Albuquerque e J. A. Guilhon Albuquerque. Rio de Janeiro: Edições Graal, 1988. 
FOUCAULT, M. O sujeito e o poder. In: DREYFUS, H.; RABINOW, P. (org.). Michel Foucault: uma trajetória filosófica para além do estruturalismo e da hermenêutica. Trad. Vera Porto Carrero. Rio de Janeiro: Forense Universitária, 1995. p. 231-249.

FOUCAULT, M. A verdade e as formas jurídicas. Trad. Roberto Cabral de Melo e Eduardo Jardim Morais. Rio de Janeiro: NAU Editora, 2002.

FOUCAULT, M. Arqueologia das ciências humanas e história dos sistemas de pensamento. Ditos \& Escritos II. Organização e coleção de textos, Manoel Barros da Motta. Trad. Elisa Monteiro. 2. ed, Rio de Janeiro: Forense Universitária, 2005a. p. 335-351.

FOUCAULT, M. Vigiar e punir: nascimento da prisão. 30. ed. Petrópolis: Vozes, 2005b.

FOUCAUlT, M. A ordem do discurso. Aula inaugural no Collège de France, pronunciada em 2 de dezembro de 1970. 13. ed. São Paulo: Edições Loyola, 2006a.

FOUCAULT, M. A vida dos homens infames. In: FOUCAULT, M. Estratégia, poder-saber. Trad. Vera Lucia Avellar Ribeiro. Ditos e Escritos IV. MOTTA, M. B. (org.). 2. ed. Rio de Janeiro: Forense Universitária, 2006b. p. 203-222.

FOUCAULT, M. Diálogo sobre o poder. In: FOUCAULT, M. Estratégia, poder-saber. Trad. Vera Lucia Avellar Ribeiro. Ditos e Escritos IV. MOTTA, M. B. (org.). 2. ed. Rio de Janeiro: Forense Universitária, 2006c. p. 253-266.

FOUCAULT, M. Conversa com Michel Foucault. In: FOUCAULT, M. Repensar a política/Michel Foucault. Ditos \& Escritos VI. Organização e coleção de textos, Manoel Barros da Motta. Trad. Ana Lúcia Paranhos Pessoa, Rio de Janeiro: Forense Universitária, 2010. p. 289-347.

GROS, F. Desobedecer. Trad. Célia Euvaldo, São Paulo: Ubu Editora, 2018.

HAROCHE, C. Antropologias da virilidade: o medo da impotência. In: CORBAIN, A.; J-J.; VIGARELO, G. História da virilidade: A virilidade em crise? Séculos XX-XXI. Trad. N. C. de M. Sobrinho e de A. e L. Florêncio. Rio de Janeiro: Vozes, 2013. p. 15-34.

MACHADO, R. Por uma genealogia do poder. In: FOUCAUL, M. Microfísica do poder. Org. e trad. Roberto Machado. 13. ed. Rio de Janeiro: Edições Graal, 1979. p. VII-XXIII.

MIRANDA, A. Z. "Guerra dos sexos": efeitos de verdade concernentes à sexualidade e à subjetividade do homem e da mulher em discursos midiáticos. 2016. 174 f. Tese (Doutorado em Letras) - Universidade Estadual de Maringá, Maringá, 2016.

NAVARRO, P.; SILVA, A. A. Discursos sobre o executivo em publicações da Revista Você S/A. In: FERNANDES, A.; CONTI, M. A.; MARQUES, W. (org.). Análise do discurso é semiologia. Uberlândia, MG: Editora da Universidade Federal de Uberlândia, 2015. p. 173-206.

NAVARRO, P. Acontecimento discursivo e efeitos de poder sobre o sujeito idoso. In: BUTTUI JUNIOR, A.; SEVERO, C. G. (org.). Foucault e as linguagens. Campinas: Pontes Editores, 2018. p. 267-296.

NUNES, M. D. de A.; CAMINHA, I. de O. O sujeito e a coragem da verdade: uma análise do último Foucault. Revista Mosaicum. Teixeira de Freitas, BA, v. 12, n. 19, p. 45-56, jan./jun. 2014. 
REDE BRASIL DE MASCULINIDADES. Página do Fabebook. Disponível em: $\underline{\text { www.facebook.com//RedeBrasildeMasculinidades. }}$ Acesso em: 10 dez. 2020

RESSIGNIFICANDO MASCULINIDADES. Página do Facebook. Disponível em:
www.facebook.com/RessignificandoMasculinidades. Acesso em: 10 dez. 2020.

\section{(ㄷ) (1) $\circledast \circledast$}

Recebido em 20/01/2021. Aceito em 04/03/2021. 